\title{
ODNOS PREBIVALSTVA OB SLOVENSKI DRŽAVNI MEJI DO PRISELJENCEV: ŠTUDIJA OBČIN KOSTEL IN OSILNICA
}

\author{
Rok ZUPANČIČ', Denis PREMEC"
}

COBISS 1.01

\section{IZVLEČEK \\ Odnos prebivalstva ob slovenski državni meji do priseljencev: Študija občin Kostel in Osilnica}

Avtorja v članku preučujeta stališča prebivalcev občin Kostel in Osilnica ob slovensko-hrvaški meji do ljudi na poti. Na tem območju skušajo migranti množično prečkati mejo, zato je posrednih ali neposrednih stikov med lokalnim prebivalstvom in migranti več kot drugod po državi. Zanimalo ju je, ali so stališča tamkajšnjega prebivalstva v primerjavi s stališči celotnega prebivalstva Slovenije o vprašanjih, povezanih z migranti, drugačna, in ali so povezana z nekaterimi demografskimi dejavniki (s spolom, starostjo, z izobrazbo, veroizpovedjo). Pričujočo mikroštudijo, ki temelji na terenski anketi, leta 2020 izvedeni v Kostelu in Osilnici, postavljata tudi v kontekst raziskav Slovensko javno mnenje.

KLJUČNE BESEDE: ljudje na poti, migranti, migracije, migrantska kriza, slovensko-hrvaška meja

\section{ABSTRACT}

The Attitudes of People Living at the Slovenian State Border Toward Immigrants:

\section{A Case Study of the Municipalities Kostel and Osilnica}

The authors explore the attitudes of residents of Kostel and Osilnica, two Slovenian municipalities bordering Croatia, toward people on the move. In this area, immigrants attempt to cross the border in large numbers; hence, the contact between the local population and the immigrants is more regular than elsewhere. The authors explore how the attitudes of locals living near the border compare to those of the general population of Slovenia and whether these attitudes are correlated with gender, age, education, and religion. The authors contextualize this micro-study, based on surveying in Kostel and Osilnica in 2020, within the large-scale surveying of Slovenia as a whole (Slovenian Public Opinion Survey).

KEYWORDS: people on the move, migrants, migrations, migrant crisis, SlovenianCroatian border

Dr. politologije (obramboslovja), izredni profesor, Fakulteta za družbene vede Univerze v Ljubljani, Kardeljeva ploščad 5, SI-1000 Ljubljana; rok.zupancic@fdv.uni-lj.si, https://orcid.org/0000-00031963-2668 - Članek je nastal v okviru programske skupine Obramboslovje P5-0206(B), ki jo sofinancira Javna agencija za raziskovalno dejavnost Republike Slovenije iz državnega proračuna.

|| Diplomirani obramboslovec, Fakulteta za družbene vede Univerze v Ljubljani, Kardeljeva ploščad 5, SI-1000 Ljubljana; dp2586@student.uni-lj.si 


\section{UVOD}

Človeške migracije so v zgodovini stalno prisoten pojav. Vzroki zanje so različni: oboroženi spopadi, ekonomska nuja, preganjanje zaradi političnega ali verskega prepričanja, podnebne spremembe, želja po boljšem življenju, razvoj transportnih možnosti in tehnološki napredek, ki migracije olajša, idr. Migracije so tudi kontroverzna tema; ker prinašajo nepoznano, sprožajo strah pred uničenjem lokalne kulture, tradicije in navad, pred prevlado migrantov - navsezadnje zato, ker naj bi imeli več otrok kot lokalno prebivalstvo. Protiargumenti in raziskave, ki dokazujejo, da imajo migranti praviloma več otrok kot lokalno prebivalstvo le v prvi in drugi »generaciji (Dubuc 2012), da migracije v EU ne potekajo nenadzorovano in tako množično, da bi bile neobvladljive (Knežević Hočevar, Cukut Krilić 2019), in druge raziskave, ki ugotavljajo, da migracije niso problematične a priori, ne prispevajo k bolj argumentiranim političnim odločitvam. Te namreč redko presegajo primordialistične interpretacije o »primerni demografski strukturi« neke nacije in ide(ologi)je, da naj bi bili narodi »organsko spojeni s svojimi ozemlji in imeli do teh ozemelj »naravne pravice« (Knežević Hočevar 2011: 11). Razlogi, da ljudje nasprotujejo migracijam, so povezani tudi z globljimi, nezavednimi strahovi, kar lahko politiki hitro »kapitalizirajo« (Tummala Narra 2020).

Del ljudi v migracijah vidi korist in meni, da so za družbo koristne (nova znanja, plemenitenje lokalne kulture, delovna sila itd.). Evolucijsko gledano sta bili obe strategiji - migrantom naklonjena in migrantom nenaklonjena ali celo sovražna - $s$ stališča razvoja človeške vrste koristni (Charlesworth 2006). Nenaklonjene oz. priseljencem sovražne strategije so bile koristne, ker so povečevale kohezivnost družb in jih ščitile pred »drugimi« (bile so pogoj za uresničitev skupnostnih ciljev); po drugi strani pa je večja odprtost do priseljencev pomenila kulturno, socialno in ekonomsko bogatenje družbe in možnost iskanja partnerjev "zunaj domačih logov«, kar je povečalo genetsko raznovrstnost družbe - s tem pa tudi preživetje (Schahbasi idr. 2020). Ni nenavadno, da sta se obe strategiji - priseljencem naklonjena in nenaklonjena oz. celo sovražna - ohranili do danes.

Na vrhuncu t. i. »migrantske krize« v letih 2015 in 2016 je v Evropo prišlo okrog milijon »ljudi na poti« - beguncev, t. i. ekonomskih migrantov in drugih ljudi, ki so se iz različnih razlogov napotili proti »stari celini« (BBC 2015). V zadnjih letih enega največjih izzivov za Evropsko unijo (EU) se je letno število migrantov, ki se uspešno prebijejo do EU, bistveno zmanjšalo. Čeprav so kot končni cilj migrantov praviloma najbolj zaželene najrazvitejše države EU (na prvih treh mestih so Nemčija, Španija in Francija), migracije niso obrobna tema niti za tranzitne države (Yıldız, Uzgören 2016); mednje sodi tudi Slovenija, prek katere vodi t. i. »balkanska pot«. Če so slovenski policisti leta 2015 zabeležili preko 360.000 nezakonitih prehodov državne meje, se je

1 Ugotovitve Sylvie Dubuc (2012) veljajo za priseljevanje iz držav z veliko rodnostjo v Veliko Britanijo v obdobju med letoma 2001 in 2006. 
leta 2019 to število zmanjšalo na nekaj več kot 16.000 nezakonitih vstopov v državo (Policija 2016; 2020).

Nekateri slovenski politiki, tudi poslanci v Evropskem parlamentu, in del medijev menijo, da je nezakonite migracije treba čimprej ustaviti ali jih vsaj omejiti (Bogovič 2019; Gregorič 2019). Ni nenavadno, da se javno mnenje o migracijah nenehno spreminja. Če je Evropska družboslovna raziskava (European Social Survey, ESS) za leto 2014 , tj. tik pred začetkom množičnih migracij, še pokazala, da so prebivalci Slovenije večinsko menili, da bi morala biti država velikodušna pri reševanju prošenj za status begunca, je dve leti pozneje, ob izrazitem povečanju števila migrantov, prišlo do preobrata; leta 2016 je bilo občutno več tistih, ki so odobritvam prošenj za status begunca nasprotovali (Zavratnik idr. 2017).

Za Slovenijo lahko rečemo, da prihaja do delne sekuritizacije migrantov, še zlasti med nekaterimi politiki. Malešič (2017) npr. ugotavlja, da je na vrhuncu migracij leta 2016 tedanja opozicija »ljudi na poti« prikazovala v poenostavljenem diskurzu, ki je pogosto temeljil na potenciranju t. i. »migrantske grožnje«. Sekuritizacija naj bi se dogajala tudi v medijih; Vezovnik (2018) na podlagi analize Dnevnika, osrednje informativne oddaje Televizije Slovenija, ugotavlja, da so bili migranti v tem obdobju vsaj implicitno, če že ne eksplicitno, uokvirjeni kot potencialna nevarnost (zdravstvena, varnostna itd.). Tudi analiza komentarjev v časopisu Delo je pokazala, da refleksije "t. i. begunske krize $v$ veliki meri ostajajo znotraj prevladujočega uokvirjanja teme $s$ strani nosilcev politične oblasti« (Pajnik 2017: 45).

Diskurz o migrantskih vprašanjih se pretežno oblikuje tam, kjer so stiki lokalnega prebivalstva $z$ »judmi na poti« najpogostejši; tovrstnih stikov je največ na območjih, prek katerih vodijo migrantske poti, npr. ob državni meji. Obmejna območja so med najbolj zanimivi območji družboslovnega proučevanja, ravno tam se nekateri družbeni pojavi zrcalijo v največji meri (Kolossov 2005). Zanimivo pa je - vsaj za primer Slovenije - da se velika večina omenjenih študij pretežno osredotoča na območje celotne države, medtem ko so obmejna območja zapostavljena. To sta tudi temeljno izhodišče najine študije in vrzel, ki jo želi najin članek (vsaj delno) zapolniti.

Osrednji cilj članka je analiza odnosa prebivalcev izbranih krajev ob meji s Hrvaško do »ljudi na poti ${ }^{2}{ }^{2}$ Osredotočila sva se na dve obmejni občini, Kostel in Osilnico, in tam izvedla anketo o odnosu prebivalcev do migracij ter iskala odgovore na naslednja raziskovalna vprašanja: prvič, kako zaskrbljeni ste zaradi množičnih migracij (beguncev, nezakonitih priseljencev in ekonomskih migrantov) in, ali vas je strah, da bi migranti lahko ogrozili način življenja v Sloveniji? Drugič, ali menite, da bi delu migrantov morali dovoliti, da trajno ostanejo v Sloveniji, ter ali jim mora biti dopuščeno gojiti lastno kulturo in religijo? In tretjič, ali so stališča prebivalcev v Osilnici in Kostelu do migrantov povezana s spolom, $z$ veroizpovedjo, s starostjo in z izobrazbo

2 V članku se izraz migrant nanaša na osebo, ki je slovensko državno mejo, $v$ večini primerov nezakonito, prestopila v zadnjih šestih letih (2015-2020), ne pa npr. na vsakodnevne migrante, kot so delavci na delu v sosednjih državah. 
lokalnega prebivalstva ter ali so stališča obmejnega prebivalstva drugačna v primerjavi s stališči celotne populacije Slovenije.

\section{TEORETSKI OKVIR: POVEZAVA MED ODNOSOM LOKALNEGA PREBIVALSTVA DO MIGRANTOV IN IZBRANIMI DEMOGRAFSKIMI DEJAVNIKI}

Teoretskih sklopov, ki pojasnjujejo odnos lokalnega prebivalstva do migrantov in dejavnikov, ki nanj vplivajo, je na desetine. V članku poudarjava le za raziskovalna vprašanja najpomembnejše dejavnike: spol, starost, religioznost in izobrazbo. Ob tem se zavedava omejitev takega fokusa - ne osredotočava se namreč na širše strukturne oz. družbene dejavnike, ki prav tako vplivajo na odnos prebivalstva do migrantov (politični kontekst oz. politično opredelitev posameznika, ekonomsko stanje $v$ državi, samoopredeljeno identiteto države, ${ }^{3}$ način ustvarjanja javnega mnenja oz. javni diskurz itd.).

\section{Povezanost spola in odnosa do migrantov}

Prevladujoče laično stališče je, da se ženske raje odločajo pomagati pomoči potrebnim, čeprav to lahko, kot ugotavlja Ticktin (2011), vodi v nekatere neželene posledice za družbo sprejemnico. ${ }^{4}$ Marsikje v oboroženih konfliktih so prav ženske osrednji steber podpore najbolj prizadetim. Razlage, zakaj je tako, gredo v več smeri. Ženske naj bi bile zaradi specifične socializacije bolj osredotočene na druge, medtem ko je za moške značilnejša osredotočenost nase. Ženske naj bi priseljenca videle kot nekoga, ki v tuji državi potrebuje pomoč, moški pa jih pretežno dojemajo kot ekonomske tekmece. Ženske naj bi se $v$ primerjavi z moškimi počutile manj ogrožene $s$ strani migrantov in tudi zato naj bi jim bile bolj naklonjene (Berg 2010). ${ }^{5}$

Po drugi strani pa naj bi bile ženske zaradi svojega družbenega statusa večje zagovornice tradicionalnih vrednot kot moški (Burns, Gimpel 2000). ${ }^{6}$ To lahko vodi do bolj negativnega odnosa žensk do migrantov, saj naj bi čutile dolžnost zaščititi

3 Nekatere države, npr. Japonska, se percepirajo kot 'normativna sila' (normative power) ali kot človekoljubnim aktivnostim naklonjena sila v mednarodnih odnosih; tako potem skušajo delovati tudi $v$ mednarodni skupnosti (glej npr. Zupančič, Hribernik 2014). Diskurz v taki državi je tako drugačen kot $v$ državi, ki svoje podobe $v$ mednarodni skupnosti ne gradi na nudenju človekoljubne pomoči.

4 Ticktin (2011) na primeru Francije argumentira, da politika sočutja lahko vodi do tega, da se v neki državi zadevam, povezanim z migranti, posveti preveč pozornosti na račun drugih, prav tako deprivilegiranih skupin, npr. revnih.

5 Berg (2010) to za ZDA ugotavlja na podlagi analize javnega mnenja za leto 2004 in popisa prebivalstva leta 2000.

6 Burns in Gimpel (2000) sta raziskavo osnovala na študiji ameriškega volilnega odločanja za leti 1992 in 1996. 
tradicionalne vrednote, da teh ne bi zamenjale tuje. A te podatke je treba vzeti cum grano salis, nekatere raziskave kažejo, da ženske predvsem pogosteje izrazijo restriktivna stališča do migracij kot moški, ki stvari raje zadržijo zase, čeprav so morda nenaklonjeni priseljevanju (Burns, Gimpel 2000). Tudi po analizi Schweitzerja idr. (2005), ki so raziskovali na podlagi anketiranja avstralskih študentk in študentov, imajo moški več predsodkov in bolj negativen odnos do migrantov.

Omenjene raziskave so bile narejene $v$ več državah sveta, tudi neevropskih. Ker je zato iz njih težko potegniti splošno veljavne teoretske zaključke, si oglejmo podatke za Evropo. Schahbasi idr. (2020) so podatke za leto 2016 proučevali v evropski družboslovni raziskavi in ugotovili, da ženske v Evropi na splošno niso bolj naklonjene migrantom kot moški; se pa skepsa do migrantov bolj poveča pri starejših ženskah kot starejših moških. Kljub vsem niansam ne moremo skleniti, da bi bil spol tisti demografski dejavnik, ki bi odločilno pojasnjeval razlike v odnosu do priseljencev.

\section{Povezanost starosti in odnosa do migrantov}

Ali je starost povezana z odnosom do migrantskih vprašanj? Pri (morda enoznačnem) odgovoru na to vprašanje je treba biti previden, saj je vanj posredno vpletenih še nekaj intervenirajočih spremenljivk (npr. posameznikov zaposlitveni status, gl. Dustmann, Preston 2007). Raziskave na splošno ugotavljajo, da je višja starost povezana $z$ večjo skepso do migrantov tako pri ženskah kot moških. $V$ primerjavi stališč ljudi v nekajletnem razmaku opazimo, da svoja stališča spreminjajo počasi in neopazno. Če pod drobnogled postavimo celotno življenje posameznika, pa ugotovimo, da običajno ljudje v različnih življenjskih obdobjih stališča do migrantov opazno spremenijo (Schahbasi idr. 2020).

Tudi ugotovitev, da so mlajši načeloma bolj odprti do priseljencev, je treba postaviti v kontekst. Mlajši so pogosto v težavnem procesu osamosvajanja, iskanja službe, urejanja stanovanjskega vprašanja itd.; zato lahko migrante dojemajo kot konkurenco. Glede na argument boja za omejene vire se lahko navežemo tudi na starejše prebivalstvo, ki se pogosto boji, da bodo njihove že pridobljene pravice izginile s prioritetne liste države ali pa da bodo na račun priseljencev okrnjene (nižja pokojnina, slabša zdravstvena oskrba; glej Hernes, Knudsen 1992).

Kako je v evropskih državah? Podatki iz ESS za leto 2016 kažejo, da višja kot je starost, večja je skepsa do migracij (Schahbasi idr. 2020). Skepsa se poveča, če se vprašanje eksplicitno nanaša na migracije iz revnih držav. Kot kažejo podatki, starejših državljanov evropskih držav ne prepričajo argumenti, da bi migranti lahko s plačilom davščin izdatno prispevali v pokojninsko blagajno ali pa da so potrebni na trgu dela, npr. za opravljanje storitev, ki jih lokalno prebivalstvo ne zmore zagotoviti $v$ celoti (slabše plačana dela, negovalne storitve itd.). 


\section{Povezanost izobrazbe in odnosa do migrantov}

Precej empiričnih raziskav je potrdilo, da imajo bolj izobraženi izrazito pozitivnejši odnos in večjo stopnjo tolerance do kulturne drugačnosti priseljencev (Morris, Heaven 1986). ${ }^{7}$ Višje izobraženi naj bi bili manj dovzetni za negativne stereotipe o »drug(ačn)ih « (priseljenci so v večini primerov pripadniki drugih etničnih skupin). K naklonjenosti bolj izobraženih do priseljevanja naj bi prispeval tudi izobraževalni proces, ki naj bi implicitno učil, da je morebitna protipriseljenska čustva bolje prikriti kot javno izraziti - Burns in Gimpel (2000) ter Berg (2010) to za ZDA utemeljujejo na podlagi analize javnomnenjskih raziskav, popisa prebivalstva in volilnega odločanja.

Osebe z višjo izobrazbo naj bi bile glede migracij bolj liberalne tudi zato, ker jih migranti manj ogrožajo, njihov položaj na trgu dela je manj ranljiv od položaja slabše izobraženih; obstaja večja verjetnost tekmovalnega (občutka) na trgu dela prav s priseljenci (Scheve, Slaughter 2001). Hkrati pa so osebe z nižjo stopnjo izobrazbe bolj čustveno vpletene $v \mathrm{z}$ delom povezana vprašanja; predvsem $\mathrm{s}$ strahom pred izgubo službe, kot na primeru Velike Britanije ugotavljata Dustmann in Preston (2007).

Večina študij potrjuje povezanost med višje izobraženimi in bolj naklonjenim odnosom do priseljencev. To potrjujejo tako izsledki za Evropo iz ESS za leto 2016, na katero se v članku na več mestih sklicujeva, kot številni avtorji (npr. Schahbasi idr. 2020).

\section{Povezanost religioznosti in odnosa do migrantov}

Pri vprašanju, ali religioznost vpliva na odnos do migrantov, ni enoznačnega odgovora. Študije dajejo nasprotujoče rezultate in nihajo od države do države ter variirajo v podrobnostih pri posameznem vprašanju. Nekatere študije tako izkazujejo, da imajo tisti, ki se izrečejo za verujoče, migrantom bolj naklonjena stališča zato, ker naj bi večina religij vsebovala ideologijo nujnosti pomoči potrebnim (Fieder, Huber 2018). ${ }^{8}$

Druge študije nakazujejo, da imajo ljudje bolj negativna stališča do priseljencev, kadar se ne morejo poistovetiti z migranti različne kulture, katere del je tudi vera; Rustenbach (2010) je to ugotovila na podlagi analize podatkov iz ESS in raziskave Eurostat/OECD. V tem duhu Facchini idr. (2013) za Južnoafriško republiko ugotavljajo, da zaradi razlike med vero lokalnega prebivalstva in vero priseljencev prihaja do priseljencem manj naklonjenih stališč. Do razlik prihaja tudi pri vprašanjih stopnje identifikacije posameznika z vero. Ysseldyk, Matheson in Anisman (2010) ugotavljajo,

7 Avtorja sta na primeru Avstralije pod drobnogled vzela stališča lokalnega prebivalstva do priseljevanja iz Vietnama.

8 Do teh sklepov sta avtorja prišla na podlagi analize podatkov iz javnomnenjskih raziskav z vsega sveta: World Value Survey 1981-2014, Survey of Health, Ageing and Retirement in Europe 2005 in US General Social Survey 1972-2014. 
da bolj kot se nekdo identificira s svojo vero, večja je verjetnost, da bo nenaklonjen ljudem druge vere. Po drugi strani pa sta Bohman in Hjerm (2014) na podlagi analize, ki je poleg več evropskih držav zajela tudi Slovenijo, ugotovila, naj bi verujoči na splošno imeli manj odklonilna stališča do migrantov kot neverujoči. Njune ugotovitve moramo interpretirati previdno, saj sta se do njih dokopala na podlagi analize podatkov iz ESS pred t. i. migrantsko krizo.

\section{METODOLOŠKI OKVIR}

Ključna metoda najine študije je bila terenska anketa. Opravila sva jo v občinah Kostel (kraji Slavski Laz, Fara, Vas in Kuželj) in Osilnica (kraji Osilnica, Sela in Bosljiva Loka). $\checkmark$ teh krajih državna meja pretežno poteka po sredini rek Kolpe in Čabranke in je razmeroma lahko prehodna. Ti kraji so bili izbrani tudi zato, ker državna meja tam ni v celoti zavarovana s t. i. tehničnimi ovirami, ki bi preprečevale nezakonit vstop v Slovenijo, zato je na tem območju precej nezakonitih prečkanj.

$\checkmark$ anketnem vprašalniku sva pretežno izhajala iz teoretskih spoznanj, ki pojasnjujejo, kateri demografski dejavniki so povezani s stališči do priseljencev. V članku analizirava le štiri dejavnike, ki se $v$ znanstveni literaturi pogosto pojavljajo $v$ povezavi z migrantskimi vprašanji: spol, starost, izobrazba in religioznost.

15. junija 2020 sva v omenjenih krajih razdelila 150 anketnih vprašalnikov v tiskani obliki. Vprašalnike sva prebivalcem izročila osebno (razdeljevanje »od hiše do hiše«) in na kratko, če je bilo mogoče, tudi pojasnila namen raziskave. Če ni bilo nikogar doma, sva vprašalnike pustila v nabiralnikih. Da bi zagotovila popolno anonimnost sodelujočih, sva neoznačenim vprašalnikom priložila kuverto s poštno znamko in prošnjo, naj anketo izpolnijo in nepodpisano pošljejo po pošti na naš naslov (to je veljalo tudi za tiste, ki so vprašalnik prejeli osebno). Vsako gospodinjstvo je prejelo dve anketi, z namenom povečanja verjetnosti, da bosta nanjo odgovarjali osebi različnega spola.

Od 150 razdeljenih anket je bilo po pošti vrnjenih in pravilno izpolnjenih 60 anket, ki so podlaga za analizo. Spolna struktura anketiranih oseb je bila uravnotežena (30 žensk in 30 moških). Starostna struktura je nagnjena na stran starejših, kar ni presenetljivo glede na demografske trende $v$ tem delu Slovenije (izseljevanje in staranje prebivalstva). ${ }^{9}$ Glede na izobrazbo je na anketo odgovarjalo največ oseb z dokončano poklicno in srednjo šolo (55 odstotkov). ${ }^{10}$ Glede na veroizpoved je anketa izrazito nesorazmerna $v$ prid verujočih, kar ni neobičajno glede na to, da je

937 odstotkov je starih 66 let ali več, 38 odstotkov med 51 in 65, 10 odstotkov jih spada v skupino 41-50 let, prav toliko tudi v skupino 31-40 let. Najmanj je mlajših odraslih; na anketo je odgovarjalo le 5 odstotkov starih med 18 in 30 let.

1025 odstotkov ima dokončano šesto, 10 odstotkov pa sedmo stopnjo izobrazbe. Trije odstotki imajo končan magisterij ali doktorat, 7 odstotkov anketiranih pa nedokončano oz. končano osnovno šolo. 
bila anketa izvedena v podeželskih krajih; kar 85 odstotkov vprašanih se je izreklo za katoličanke oz. katolike, 12 odstotkov pa za neverujoče. ${ }^{11}$

O veljavnosti in zanesljivosti študije ter interpretaciji je treba poudariti, da zato, ker gre za mikroštudijo, anketa ni reprezentativna. Zaradi specifičnega načina pridobivanja podatkov (osebno razdeljevanje anket) vzorca ni bilo mogoče kontrolirati. Ankete so bile $v$ nekaterih krajih razdeljene $v$ vsa gospodinjstva, $v$ drugih, večjih, pa je bilo razdeljevanje naključno; dodati je treba, da nekateri ankete niso želeli sprejeti. Zato se ne ve, kako dobro ankete, ki tvorijo najin vzorec, odražajo dejanske demografske značilnosti prebivalstva $v$ obeh občinah. $V$ vsakem primeru je treba rezultate interpretirati previdno in jih kontekstualizirati v luči drugih raziskav. Kot kontekst, $\checkmark$ katerega postavljava izsledke najine študije, sva vzela raziskave Slovensko javno mnenje, narejeno na reprezentativnem vzorcu (Kurdija, Malnar 2018 - v nadaljevanju SJM2016/2; Kurdija, Malnar 2016 - v nadaljevanju SJM2014). S pomočjo programa SPSS sva na vzorcu, ki odraža stališča prebivalcev in prebivalk Slovenije kot celote, analizirala izbrane demografske dejavnike glede na odnos do izbranih vprašanj.

\section{REZULTATI IN DISKUSIJA}

V nadaljevanju predstavljava analizo ankete po proučevanih dejavnikih: spolu, starosti, izobrazbi in religioznosti. $V$ članku navajava le najzanimivejše izsledke. ${ }^{12}$

\section{Povezanost spola in odnosa do migrantov}

Prebivalke krajev, kjer sva opravila anketo, so vprašanju »Ali se vam zdi dopustno, da bi del migrantov trajno ostal v Sloveniji (67 odstotkov) anketirank meni, da je nedopustno, da bi del migrantov trajno ostal v Sloveniji; če pogledamo zgolj moške, jih tako meni dobra polovica (53 odstotkov).

Pri odgovoru na vprašanje »Ali vas je strah, da bi migranti lahko ogrozili način življenja v Sloveniji« - eksplicitno sva zapisala, da mislimo begunce, nezakonite priseljence in t. i. ekonomske migrante - vidimo, da je 30 odstotkov žensk zelo ali precej strah, da bi se to lahko zgodilo, medtem ko je tega zelo ali precej strah le 13 odstotkov moških. Kljub temu pa med ženskami in moškimi ni bistvenih razlik pri vprašanju, ali bi migrantom morali dopustiti, da v Sloveniji gojijo lastno kulturo in religijo; s to trditvijo se strinja zgolj 17 odstotkov moških in 13 odstotkov žensk, kar nakazuje na jasno stališče, da tako večina moških kot žensk temu ni naklonjena.

11 1,5 odstotka vprašanih ni želelo odgovoriti na vprašanje o veroizpovedi, prav toliko pa je pripadnikov drugih ver.

12 Nekatera druga stališča odnosa prebivalcev obmejnih krajev do priseljencev so podrobneje predstavljena v diplomskem delu (Premec 2020), katerega podatki so bili podlaga za pripravo pričujočega članka. 
Po drugi strani pa dejavnik spola ne vpliva bistveno na zaskrbljenost zaradi množičnih migracij. Analiza je pokazala, da je zelo zaskrbljenih ali dokaj zaskrbljenih le malenkost več žensk kot moških (77 odstotkov v primerjavi s 73 odstotki). Ne glede na to pa je rezultate treba interpretirati s stališča razmeroma velikega strahu tako moških kot žensk; le približno četrtina vprašanih (moških in žensk) je izrazila stališče, da ni preveč ali da sploh ni zaskrbljena. Večina tako moških kot žensk meni, da migranti zelo ali vsaj srednje močno ogrožajo varnost Slovenije; treba je dodati, da so odgovori moških v primerjavi z ženskami bolj raznoliki; ženske so bolj enotnega mnenja, da migranti varnost Slovenije ogrožajo zelo oz. srednje močno. Prav tako oba spola večinsko soglašata, brez bistvenih medsebojnih razlik, da migranti v Slovenijo niso prišli zaradi preganjanja v matični državi, temveč iz drugih razlogov.

\section{Povezanost starosti in odnosa do migrantov}

Mlajšim v Kostelu in Osilnici se zdi v večji meri dopustno, da bi del migrantov brezpogojno ali pod določenimi pogoji ostal v Sloveniji; tako meni dobra polovica (53 odstotkov) starih med 18 in 50 let. Starejša populacija je na to vprašanje odgovarjala manj naklonjeno; od tistih, ki so stari 51 let ali več, se s to trditvijo strinja le 36 odstotkov vprašanih.

Ti rezultati ne presenečajo, če jih povežemo z vprašanjem o strahu; upokojenci - najstarejša skupina - menijo, da priseljenci zelo ogrožajo varnost Slovenije (tako meni 48 odstotkov vprašanih). Da priseljenci zelo ogrožajo varnost države, meni le dobra četrtina delovno aktivnih ( 26 odstotkov). Tem rezultatom je treba dodati še odgovore na povezano vprašanje, in sicer, ali bi migrantom moralo biti v Sloveniji dopuščeno gojiti lastni kulturo in vero. Upokojenci se v veliki večini (91 odstotkov) ne strinjajo, da bi ta pravica morala veljati tudi za migrante, medtem ko je mlajša skupina redno zaposlenih temu malo bolj naklonjena (trditvi nasprotuje »le« 74 odstotkov sodelujočih).

Da je odnos do migrantskih vprašanj kompleksen in da bi bilo narobe starejšim a priori pripisati bolj odklonilna stališča, nakazujejo odgovori na vprašanje, ali bi bili brezpogojno ali pod nekaterimi pogoji pripravljeni pomagati migrantom. Starejši so namreč izrazili večjo pripravljenost pomagati kot mlajši (73 odstotkov starih 66 ali več je pripravljeno pomagati, medtem ko ta delež za skupino od 51 do 65 let znaša 43,5 odstotka). Ne preseneča, da so starejši, kot je pokazala anketa, v preteklosti večkrat kot mlajši tudi dejansko pomagali. Pri tem vprašanju je treba dodati, da se pripravljenost pomagati migrantom v Sloveniji sčasoma spreminja, kar so ugotovili tudi drugi (Zavratnik idr. 2017). Na nekaj anketnih vprašalnikih je bilo dopisano, da so v preteklosti sicer migrantom pomagali, da pa zdaj tega ne bodo več, ker so (nekateri) migranti pomoč izrabili, so nehvaležni oz. celo povzročajo škodo. Najpogosteje so anketiranci pomagali z informacijami, občasno tudi materialno (s hrano in pijačo), nekateri pa celo s prenočiščem. 


\section{Povezanost izobrazbe in odnosa do migrantov}

Bolj izobraženi v krajih anketiranja so bolj naklonjeni, da bi del migrantov ob določenih pogojih ali brezpogojno ostal v Sloveniji. 39 odstotkov tistih, ki imajo dokončano vsaj šesto stopnjo izobrazbe ali več, namreč meni, da je nedopustno, da migranti trajno ostanejo $v$ Sloveniji, medtem ko je med manj izobraženimi (nedokončana ali dokončana osnovna šola, poklicna ali srednja šola) ta odstotek bistveno višji - kar 73 odstotkov jih meni, da je nedopustno, da del migrantov trajno ostane v Sloveniji.

Ti rezultati niso presenetljivi, če jih povežemo $z$ vprašanjem glede strahu pred migranti. 84 odstotkov manj izobraženih je izrazilo stališče, da so zelo ali pa vsaj dokaj zaskrbljeni zaradi migracij; v skupini višje izobraženih je zelo ali dokaj zaskrbljenih manj (61 odstotkov). To je povezano tudi z mnenjem o tem, ali migranti ogrožajo varnost Slovenije. 45 odstotkov nižje izobraženih meni, da migranti zelo ogrožajo varnost države, medtem ko je delež pri tistih z višjo izobrazbo precej nižji - da migranti zelo ogrožajo varnost Slovenije, meni le sedem odstotkov višje izobraženih (pri skupini višje izobraženih sicer prevladuje odgovor, da migranti »srednje močno« ogrožajo varnost Slovenije; tako meni 64 odstotkov višje izobraženih).

Strah manj izobraženih se kaže tudi pri odgovoru, ali jih je strah, da bi migranti ogrozili način življenja v Sloveniji. 73 odstotkov manj izobraženih je zelo ali precej strah, da bi se to lahko zgodilo. Višje izobraženi so glede tega manj zaskrbljeni; manj kot polovica vprašanih (48 odstotkov) jih je zelo ali precej strah. Manj izobraženi menijo, da migrantom ni treba omogočiti znosnega življenja v Sloveniji; trditvi »migrantom je treba omogočiti znosno življenje v Sloveniji« nasprotuje 79 odstotkov nižje izobraženih, kar je bistvena razlika v primerjavi z le 39 odstotki višje izobraženih, ki tej trditvi nasprotujejo. Razlike med nižje in višje izobraženimi so še bolj opazne pri vprašanju o tem, ali bi migrantom morali dopustiti gojenje lastne kulture in vere; 94 odstotkov nižje izobraženih se ne strinja, da jim to mora biti omogočeno, medtem ko so višje izobraženi temu razmeroma bolj naklonjeni, nikakor pa ne zelo naklonjeni (63 odstotkov višje izobraženih se ne strinja, da je migrantom v Sloveniji treba omogočiti gojenje lastne vere in kulture).

\section{Povezanost religioznosti in odnosa do migrantov}

Anketiranci/-ke, ki so se opredelili/e za katoliki/-nje, so manj naklonjeni, da bi del migrantov ostal v Sloveniji; le tretjina (33 odstotkov) katolikov/katoličank meni, da je dopustno, da del migrantov pod določenimi pogoji ali brezpogojno trajno ostane $v$ Sloveniji, medtem ko je med neverujočimi ta delež 71-odstoten. Verjetno so odgovori na to vprašanje povezani s strahom in z negotovostjo, ki ju prinašajo migranti. Velika večina tistih, ki so se izrekli za katolike oz. katoličanke, je zaradi množičnih migracij zelo ali dokaj zaskrbljena (tako je odgovorilo 82 odstotkov deklariranih katolikov/-čank), medtem ko so odgovori neverujočih po lestvici enakomerneje razporejeni (43 
odstotkov neverujočih je dokaj ali zelo zaskrbljenih, 57 odstotkov pa sploh ni zaskrbljenih ali pa niso preveč zaskrbljeni).

Ti odgovori so, kot je pokazala raziskava, povezani tudi z odgovorom na vprašanje, ali je migrantom treba omogočiti znosno življenje $v$ Sloveniji. $S$ to trditvijo se strinja le 28 odstotkov tistih, ki so se v anketi izrekli za katolike/-čanke, kar je bistvena razlika v primerjavi z neverujočimi; od teh jih kar 80 odstotkov meni, da je migrantom, ki pridejo $v$ Slovenijo, treba omogočiti znosno življenje. Zelo verjetno je, da so ti odgovori neposredno povezani $z$ večjim strahom in negotovostjo katolikov/-čank pred migranti; 71 odstotkov pripadnikov oz. pripadnic katoliške vere je zelo ali vsaj precej strah, da bi migranti lahko ogrozili način življenja v Sloveniji, medtem ko so neverujoči manj prestrašeni - 57 odstotkov vprašanih tega sploh ali pa v glavnem ni strah.

\section{Interpretacija mikroštudije v kontekstu slovenskega javnega mnenja}

$V$ tem delu članka rezultate mikroštudije iz Osilnice in Kostela interpretirava glede na relevantna vprašanja iz raziskav, narejenih na celotnem vzorcu prebivalstva Slovenije. Primerjava podatkov iz raziskav SJM2014 in SJM2016/2 pokaže, da je naklonjenost prebivalk in prebivalcev Slovenije priseljencem pred t. i. migrantsko krizo in po njenem začetku upadla. Če je leta 2014 še 14 odstotkov Slovencev menilo, naj Slovenija mnogim ljudem drugačnega narodnostnega izvora dovoli priseljevanje, je leta 2016 ta odstotek padel na osem. Narasel pa je delež tistih, ki menijo, naj Slovenija le redkim z drugačnim narodnostnim izvorom dovoli priseljevanje - s 24 odstotkov leta 2014 na 35 odstotkov leta 2016 (Kurdija, Malnar 2016; 2018). Odgovori na vprašanje o priseljevanju iz revnih držav v Slovenijo so podobni. Zavratnik idr. (2017) na podlagi analize SJM2016/2 ugotavljajo, da je takrat 13 odstotkov prebivalk in prebivalcev Slovenije menilo, da se nikomur iz revnejših držav zunaj Evrope ne sme dovoliti priseljevanja v Slovenijo, 33 odstotkov, da mora biti to dovoljeno zelo redkim, medtem ko je 43 odstotkov menilo, naj se nekaterim dovoli, oz. 9 odstotkov, naj se mnogim dovoli.

Rezultate najine študije primerjava še $z$ javnomnenjsko raziskavo SJM2016/2 (Kurdija, Malnar 2018), in sicer s stališča izbranih demografskih dejavnikov (spola, izobrazbe, starosti, religioznosti). Izračune sva naredila s pomočjo statističnega programa SPSS.

Začenjava z dejavnikom spola. Izkazalo se je, da so ženske $v$ Sloveniji malo manj naklonjene priseljevanju ljudi $z$ drugačnim narodnostnim izvorom kot večina prebivalcev Slovenije; le 6,8 odstotka žensk meni, naj se mnogim priseljencem dovoli priselitev v Slovenijo (v primerjavi z 10,2 odstotka moških), 35,8 odstotka jih meni, naj se priselitev dovoli zelo redkim ljudem drugačnega narodnostnega izvora (v primerjavi s 33,9 odstotka moških). Ženske le v malo večji meri kot moški menijo, da je kulturno življenje v Sloveniji zaradi priseljencev na splošno ogroženo; za ilustracijo še podatek, da se je na kontinuumu od 0 do 10, kjer 0 pomeni, da je kulturno življenje ogroženo, 
$10 \mathrm{pa}$, da je kulturno življenje obogateno, za »skrajno oceno« 0 odločilo 7,3 odstotka žensk in 6,2 odstotka moških. Razlike med skupinama niso statistično značilne.

Analiza dejavnika starost v SJM2016/2 (Kurdija, Malnar 2018) pokaže, da naklonjenost prebivalk in prebivalcev Slovenije priseljevanju ljudi iz revnejših neevropskih držav pada s starostjo. V starostni skupini 19-30 let jih 16,3 odstotka meni, da je mnogim priseljencem iz neevropskih držav treba dovoliti priselitev, $v$ starostni skupini 31-45 let jih tako misli 10,7 odstotka, v skupini $46-60$ let 7,6 odstotka, medtem ko se le 4,4 odstotka starih 61 let in več strinja s to trditvijo. Logika pri trditvi, naj Slovenija zelo redkim iz revnejših neevropskih držav dovoli priselitev, je enaka. Najstarejši se najbolj strinjajo, najmlajši najmanj.

Naslednji obravnavani demografski dejavnik je izobrazba. Če ga postavimo v kontekst podatkov iz SJM2016/2, ugotovimo, da je za Slovenijo značilno, da je stopnja izobrazbe premo sorazmerna z naklonjenostjo priseljevanju iz revnejših neevropskih držav; le redki nižje izobraženi se strinjajo, da mora Slovenija dopustiti priseljevanje iz revnejših neevropskih držav (delež tako mislečih z nepopolno ali popolno osnovnošolsko izobrazbo, z nižjo ali s srednjo poklicno izobrazbo ali srednjo strokovno izobrazbo se giblje med 3,3 odstotka in 7 odstotki), strmo pa naraste pri visokošolsko univerzitetno izobraženih - tako jih meni kar 17,1 odstotka. Deleži naraščajo vse do doktorata; kar 37,5 odstotka oseb z doktoratom meni, da bi Slovenija morala dopustiti priseljevanje iz revnih neevropskih držav. Trend je ravno obraten pri trditvi, da Slovenija nikomur iz revnejših neevropskih držav ne bi smela dopustiti priselitve (Kurdija, Malnar 2018).

Zadnji obravnavani dejavnik v raziskavi je bila pripadnost določeni veroizpovedi (religioznost). Če jo postavimo v kontekst SJM2016/2, ugotovimo, da so na vzorcu celotne populacije Slovenije tisti, ki so se izrekli, da ne pripadajo nobeni veroizpovedi, bolj naklonjeni priseljevanju iz revnejših neevropskih držav kot pa pripadniki in pripadnice neke veroizpovedi. Da naj Slovenija mnogim iz teh držav dovoli priselitev, meni 56,4 odstotka tistih, ki ne pripadajo nobeni veroizpovedi. Medtem pa se le 42,7 odstotka tistih, ki pripadajo eni od veroizpovedi, s to trditvijo strinja. Skladno s tem prihaja do razlik med skupinama pri trditvi, naj Slovenija nikomur iz revnejših neevropskih držav ne dovoli priselitve; 66,5 odstotka tistih, ki pripadajo neki veroizpovedi, meni, da priseljevanja ne bi smeli dovoliti nikomur, medtem pa tako meni le 33,5 odstotka tistih, ki ne pripadajo nobeni veroizpovedi.

Poglejmo še podatke iz SJM2016/2 za katolike in katoličanke: od tistih, ki so se tako izrekli, jih je 5,5 odstotka menilo, da bi morali mnogim iz revnejših neevropskih držav dovoliti priselitev $v$ Slovenijo, 38,8 odstotka katoličank oz. katoličanov je menilo, da naj bo priselitev dovoljena zgolj nekaterim, 37,7 odstotka, da zelo redkim, medtem ko 15,2 odstotka katolikov oz. katoličank meni, da tega ne bi smeli dovoliti nikomur. ${ }^{13}$ Tudi Smrke (2019) je ugotovil, da je »učinek krščanskega humanizma«, kar

13 Izračun upošteva tudi tiste katolike in katoličanke, ki so na vprašanje odgovorili »ne vem«, so zavrnili odgovarjanje ali pa odgovora niso podali, zato seštevek zgornjih odstotkov ni enak 100. 
se tiče katolištva, opaziti šele $v$ ozki kategoriji zelo vernih in da so do tujcev praviloma manj distancirani tisti, ki ne pripadajo neki verski skupnosti oz. tisti, ki verskih obredov ne obiskujejo.

\section{SKLEP}

V članku sva iskala odgovore na vprašanja, kako zaskrbljeni so prebivalci Osilnice in Kostela zaradi množičnih migracij, ali jih je strah, da bi migranti ogrozili način življenja v Sloveniji, ali bi moralo biti delu migrantov dopuščeno, da trajno ostane v Sloveniji in, ali jim mora biti dovoljeno gojiti lastni kulturo in religijo. Zanimalo naju je tudi, ali obstaja povezanost med izbranimi demografskimi značilnostmi prebivalstva in stališči do migrantov. Stališča prebivalcev obmejnih občin sva na podlagi statistične analize raziskav SJM 2014 in SJM2016/2 primerjala s stališči celotne populacije Slovenije.

Analiza 60 anketnih vprašalnikov je pokazala, da so prebivalci slovenskih obmejnih krajev razmeroma nenaklonjeni migrantom in da se, splošno gledano, migracij bojijo $z$ več vidikov. Verjetno so $k$ strahu prispevale razmere glede novega koronavirusa, saj je gibanje vseh ljudi, torej tudi »ljudi na poti«, razumljeno kot pomemben dejavnik, ki prispeva k širjenju virusa (raziskovala sva junija 2020, ob koncu prvega vala koronavirusa). Anketiranci so bili razmeroma enotni glede trditve, da je treba migrante vrniti v matične države, ko tam grožnja, zaradi katere so jo zapustili, preneha. $V$ prid ugotovitvi o sorazmerni nenaklonjenosti do migrantov $v$ proučevanih občinah govori tudi podatek, da se velika večina vprašanih ne strinja, da bi migrantom v Sloveniji morali dopustiti gojenje lastne kulture in vere.

Analiza po spolu glede na obstoječe teorije ni dala presenetljivih rezultatov. Ženskam v obmejnih krajih se sicer malenkostno bolj kot moškim zdi nedopustno, da bi del migrantov ostal v Sloveniji, hkrati pa izražajo pred migranti le malo večji strah kot moški. Razlike $v$ stališčih so glede na spol razmeroma majhne in statistično neznačilne. Do enakih ugotovitev pridemo, če stališča prebivalstva ob meji primerjamo z ugotovitvami, pridobljenimi na podlagi analiz SJM2016/2 in SJM2014.

Analiza je pokazala, da so višje izobraženi večinoma manj prestrašeni glede (domnevne) ogroženosti načina življenja v Sloveniji s strani migrantov. Višje izobraženi so $v$ primerjavi z nižje izobraženimi tudi bolj naklonjeni, da del migrantov trajno ostane $v$ Sloveniji. To se ujema tudi s stališči ljudi, anketiranih v SJM, je pa najina študija pokazala, da so stališča ob državni meji bolj odklonilna. $S$ stališča teorije je pomembna tudi ugotovitev, da so višje izobraženi bolj pripravljeni pomagati migrantom kot nižje izobraženi. Kot kažejo rezultati, so tudi v obmejnih krajih manj izobraženi bolj dovzetni za argumente, da bodo migranti ogrozili »slovensko narodno bit« in da za Slovenijo niso koristni. ${ }^{14}$

14 Pri tem je treba opozoriti tudi na ekonomsko-socialni vidik. Nižje izobraženi imajo praviloma nižje dohodke, so praviloma revnejši in bolj socialno izključeni, kar vodi v večje nezaupanje. 
Za pojasnjevanje stališč do migracij je pomemben dejavnik tudi veroizpoved. Verujoči, ki so se v anketi izrekli za katolike/-čanke, so precej bolj zaskrbljeni glede migracij in so jim manj naklonjeni kot neverujoči. Te ugotovitve veljajo, kot je pokazala analiza SJM2016/2, tudi za celotno slovensko populacijo, vendar so stališča ob meji bolj odklonilna. Vprašati se je treba po vzroku za nizko katoliško sočutje do migrantov v primerjavi z neverujočimi, kar je za Slovenijo ugotovil že Smrke (2019), oz., ali se to sočutje izraža kako drugače (zanimiva bi bila analiza katoliških medijev ali cerkvenih pridig $v$ teh krajih). Hkrati je treba dodati, da je najina študija pokazala, da so katoliki in katoličanke primerljivi z neverujočimi glede tega, ali so migrantom v preteklosti že dejansko pomagali ( $z$ informacijami, s hrano in pijačo ipd.).

Analizo končujeva z dejavnikom starosti. Čeprav se po rezultatih ankete dozdeva, da so mlajši razmeroma bolj odprti do migrantov, ker bolj kot starejši dopuščajo, da bi del migrantov trajno ostal v Sloveniji (do takšnih ugotovitev sva prišla tudi na podlagi analize SJM2016/2), je treba biti pri interpretaciji pazljiv, saj odgovor ni enoznačen. Glede konkretne pomoči je anketa pokazala, da so starejši bolj kot mlajši pripravljeni pomagati migrantom. Tudi pri tem dejavniku - kot tudi pri vseh preostalih - gre le za indikativne, kljub vsemu pa pomembne rezultate. Za bolj konkluzivne sklepe bi morala dodatne analize opraviti na reprezentativnem vzorcu.

Iz pogovorov $z$ anketiranimi med vročanjem anket in pripisov na vprašalnikih sva razbrala, da je bila naklonjenost obmejnega prebivalstva v preteklosti (npr. leta 2015 , ko so migranti začeli množično prihajati v Slovenijo) višja kot na dan izvedbe ankete, ko je na to območje že pet let prihajalo večje število migrantov. Sklepava, da naklonjenost do migrantov in z njo povezana pomoč - naj gre za begunce ali za t. i. ekonomske migrante - trajata, dokler na neko območje, ki ga smatramo za ekskluzivno »svoje«, migranti ne začnejo množično prihajati (kar ugotavljajo tudi Zavratnik idr. 2017) ali se celo zatekati h kaznivim dejanjem - npr. vlomom. To se ob Kolpi in Čabranki sicer dogaja, a je teh dogodkov glede na množičnost migracij razmeroma malo in v zadnjih letih v teh krajih ni zaznati naraščanja teh dejanj (Hacin 2020). Glede na uvodoma predstavljene evolucijske in psihosocialne teorije nenaklonjenost ali celo odpor do priseljencev ne presenečata. $V$ človeškem umu vedno obstajajo »naši«, »malo manj naši« in »sploh ne naši«.

\section{LITERATURA IN VIRI}

BBC (2015). Migrant Crisis: One Million enter Europe in 2015, https://www.bbc.com/ news/world-europe-35158769 (8. 10. 2020).

Berg, Justin Allen (2010). Race, Class, Gender, and Social Space: Using an Intersectional Approach to Study Immigration Attitudes. The Sociological Quarterly 51/2, 278-302, https://doi.org/10.1111/j.1533-8525.2010.01172.x.

Bogovič, Franc (2019). Nezakonite migracije je treba ustaviti na meji, http://bogovic.eu/ nezakonite-migracije-je-treba-ustaviti-na-meji/ (8. 10. 2020). 
Bohman, Andrea, Hjerm, Mikael (2014). How the Religious Context Affects the Relationship Between Religiosity and Attitudes Towards Immigration. Ethnic and Racial Studies 37/6, 937-957, https://doi.org/10.1080/01419870.2012.748210.

Burns, Peter, Gimpel, James G. (2000). Economic Insecurity, Prejudicial Stereotypes, and Public Opinion on Immigration Policy. Political Science Quarterly 115/2, 201-225, https://doi.org/10.2307/2657900.

Charlesworth, Deborah (2006). Balancing Selection and its Effects on Sequences in Nearby Genome Regions. PLoS Genetics 2/4, 379-384, https://doi.org/10.1371/ journal.pgen.0020064.

Dubuc, Sylvie (2012). Immigration to the UK from High-fertility Countries: Intergenerational Adaptation and Fertility Convergence. Population and Development Review 38/2, 353-368, https://doi.org/10.1111/j.1728-4457.2012.00496.x.

Dustmann, Christian, Preston, lan P. (2007). Racial and Economic Factors in Attitudes to Immigration. The B. E. Journal of Economic Analysis \& Policy 7/1, 1-39, https:// doi.org/10.2202/1935-1682.1655.

Facchini, Giovanni, Mayda, Anna Maria, Mendola, Mariapia (2013). What Drives Individual Attitudes towards Immigration in South Africa? Review of International Economics 21/2, 326-341, https://doi.org/10.1111/roie.12039.

Fieder, Martin, Huber, Susanne (2018). Political Attitude and Fertility: Is there a Selection for the Political Extreme? Frontiers in Psychology 9/2343, 1-11, https://doi. org/10.3389/fpsyg.2018.02343.

Finseraas, Henning, Skorge, Øyvind Søraas, Strøm, Marte (2018). Does Education Affect Immigration Attitudes? Evidence from an Education Reform. Electoral Studies 55, 131-135, https://doi.org/10.1016/j.electstud.2018.06.009.

Gregorič, Milan (2019). Evropa je na široko odprla vrata islamu in se mu podredila, https://www.casnik.si/ilegalne-migracije-je-treba-ustaviti/ (26. 11. 2020).

Hacin, Rok (2020). Kriminaliteta v občinah ob schengenski meji. 6. Nacionalna konferenca o varnosti $v$ lokalnih skupnostih: Varnost $v$ ruralnih in urbanih okoljih: Konferenčni zbornik (ur. Gorazd Meško, Rok Hacin, Katja Eman). Maribor: Univerzitetna založba, 109-116, https://doi.org/10.18690/978-961-286-404-0.11.

Hernes, Gudmund, Knudsen, Knud (1992). Norwegians' Attitudes toward New Immigrants. Acta Sociologica 35/2, 123-139, http://dx.doi.org/10.1177/ 000169939203500204.

Ilegalne migracije na območju Republike Slovenije (2020), https://www.policija.si/ images/stories/Statistika/MejnaProblematika/IlegalneMigracije/2019/Januar-december_2019.pdf (8. 10.2020).

Knežević Hočevar, Duška (2011). Obrazi migracij v govoru o rodnosti. Dve domovini / Two Homelands 33, 7-22.

Knežević Hočevar, Duška, Cukut Krilić, Sanja (2019). Delovna mobilnost in migracije v vprašljivem demografskem umovanju. Dve domovini / Two Homelands 50, 131-146, https://doi.org/10.3986/dd.v2019i50.7462. 
Kolossov, Vladimir (2005). Border Studies: Changing Perspectives and Theoretical Approaches. Geopolitics 10/4, 606-632, https://doi.org/10.1080/ 14650040500318415.

Kurdija, Slavko, Malnar, Brina (2016). Slovensko javno mnenje 2014: Evropska družboslovna raziskava. Ljubljana: Univerza v Ljubljani, Arhiv družboslovnih podatkov, https://doi.org/10.17898/ADP_SJM14_V1.

Malešič, Marjan (2017). The Securitisation of Migrations in Europe: The Case of Slovenia. Teorija in praksa 54/6, 947-968.

Morris, John W., Heaven, Patrick C. L. (1986). Attitudes and Behavioral Intentions toward Vietnamese in Australia. Journal of Social Psychology 126/4, 513-520, https://doi.org/10.1080/00224545.1986.9713619.

Policija (2016). Ilegalne migracije na območju Republike Slovenije, https://www. policija.si/images/stories/Statistika/MejnaProblematika/llegalneMigracije/2015/ December2015.pdf (8. 10. 2020).

Premec, Denis (2020). Odnos prebivalcev slovenskih obmejnih krajev do migrantov: Študija primera izbranih krajev v občinah Kostel in Osilnica. Diplomsko delo. Ljubljana: Fakulteta za družbene vede Univerze v Ljubljani.

Rustenbach, Elisa (2010). Sources of Negative Attitudes toward Immigrants in Europe: A Multi-Level Analysis. The International Migration Review 44/1, 53-77, https://doi. org/10.1111\%2Fj.1747-7379.2009.00798.x.

Schahbasi, Alexander, Huber, Susanne, Fieder, Martin (2020). Factors Affecting Attitudes toward Migrants - An Evolutionary Approach. American Journal of Human Biology e23435, https://doi.org/10.1002/ajhb.23435.

Scheve, Kenneth F., Slaughter, Matthew J. (2001). Labor Market Competition and Individual Preferences over Immigration Policy. The Review of Economics and Statistics 83/1, 133-145, https://doi.org/10.1162/003465301750160108.

Schweitzer, Robert, Perkoulidis, Shelley, Krome, Sandra, Ludlow, Christopher, Ryan, Melanie (2005). Attitudes towards Refugees: The Dark Side of Prejudice in Australia. Australian Journal of Psychology 57/3, 170-179, https://doi. org/10.1080/00049530500125199.

Slovensko javno mnenje 2016/2 (2018). Evropska družboslovna raziskava. Ljubljana: Univerza v Ljubljani, ADP, https://doi.org/10.17898/ADP_SJM162_V1.

Smrke, Marjan (2019). Religioznost in velikodušnost do migrantov. Dve domovini / Two Homelands 50, 199-216, https://doi.org/10.3986/dd.v2019i50.7466.

Ticktin, Miriam (2011). Casualties of Care: Immigration and the Politics of Humanitarianism in France. University of California Press.

Tummala Narra, Pratyusha (2020). The Fear of Immigrants. Psychoanalytic Psychology 37/1, 50-61, https://doi.org/10.1037/pap0000245.

Vezovnik, Andreja (2018). Securitizing Migration in Slovenia: A Discourse Analysis of the Slovenian Refugee Situation. Journal of Immigrant \& Refugee Studies 16/1-2, 39-56, https://doi.org/10.1080/15562948.2017.1282576. 
Yıldız, Ayselin, Uzgören, Elif (2016). Limits to Temporary Protection: Non-camp Syrian Refugees in Izmir, Turkey. Southeast European and Black Sea Studies 16/2, 195-211, https://doi.org/10.1080/14683857.2016.1165492.

Ysseldyk, Renate, Matheson, Kimberly, Anisman, Hymie (2010). Religiosity as Identity: Toward an Understanding of Religion from a Social Identity Perspective. Personality and Social Psychology Review 14/1, 60-71, https://doi. org/10.1177\%2F1088868309349693.

Zavratnik, Simona, Broder, Živa, Falle Zorman, Rebeka (2017). Javno mnenje in migracije: Mehanizmi klasifikacij in »begunska kriza«. Teorija in praksa 54/5, 857-884.

Zupančič, Rok, Hribernik, Miha (2014). "Discovering" Normative Power as a State Strategy in the Framework of Security, Foreign, and Defense Policy: The Case of Japan. Philippine Political Science Journal 35/1, 78-97, https://doi.org/10.1080/011 54451.2014.903566. 


\section{SUMMARY}

\section{THE ATTITUDES OF PEOPLE LIVING AT THE SLOVENIAN STATE BORDER TOWARD IMMIGRANTS: A CASE STUDY OF THE MUNICIPALITIES KOSTEL AND OSILNICA Rok ZUPANČIČ, Denis REMEC}

This paper explores the attitudes of the residents of Kostel and Osilnica, two Slovenian municipalities on the border of Croatia, toward the "people on the move" (immigrants who started arriving in Slovenia in large numbers from 2015 on). The authors, relying on the micro-survey conducted in the two municipalities in 2020 , found that the local population there has, generally speaking, rather negative attitudes toward these immigrants. They are afraid of immigration for various reasons (security, cultural and identity issues, etc.) and agree that the immigrants should leave Slovenia as soon as the danger that forced them to leave their native countries has gone.

Later in the paper, the authors contextualize their data, acquired in Kostel and Osilnica, within the wider context of surveys done in Slovenia as a whole (general sample). They aim to determine whether the local population's attitudes in the border region are similar to the country's general population (Slovenian Public Opinion Poll Surveying 2014 and 2016/2). The authors learned that the local population has more negative attitudes in all explored respects than the general population. In their study, women have slightly more negative attitudes toward immigrants than men; however, these differences are not statistically significant. This finding corresponds with the data in the general sample of people living in Slovenia.

Furthermore, the level of education is correlated with a positive attitude toward the immigrants - the more educated the person, the more positive the attitude toward the immigrants. The religious people in the bordering region have shown a less positive attitude toward the immigrants, compared to the non-religious people surveyed in their micro-study. The last demographic factor analyzed was age - the higher the age, the more negative the attitude toward the immigrants. 